\title{
Analisis Flourishing Mantan Pecandu Alkohol di Desa Sumili Kecamatan Kupang Barat
}

\author{
Ilyanti A. Surah \\ Konseling Pastoral Sekolah Tinggi Agama Kristem Negeri Kupang \\ ilyantisurah96@gmail.com \\ Friandry Windisany Thoomaszen \\ Konseling Pastoral Sekolah Tinggi Agama Kristem Negeri Kupang \\ windisany90@gmail.com
}

Infromasi Artikel

\begin{tabular}{ll}
\hline Tanggal masuk & $29-02-2020$ \\
Tanggal revisi & $17-06-2020$ \\
Tanggal diterima & $09-07-2020$
\end{tabular}

Kata Kunci:

polisi;

reserse kriminal umum;

sabhara;

stres kerja.
Abstrak

Suatu pilihan yang tidak mudah bagi seorang pecandu alkohol untuk terlepas dari ketergantungannya pada zat psikoaktif ini. Karena itu, dalam penelitian ini menggunakan pendekatan psikologi positif sebagai landasan menganalisa flourishing mantan pecandu alkohol di Desa Sumlili. Metode kualitatif dengan teknik pengambilan data berupa observasi non-partisipan dan wawancara semi terstruktur dilakukan pada 4 subjek dewasa yang telah berhenti mengonsumsi alkohol sejak 2 tahun, 4 tahun, 5 tahun, dan 9 tahun. Triangulasi dilakukan dengan observasi dan wawancara keluarga subjek. Teknik pengambilan sampel menggunakan purposive sampling. Hasil penelitian menunjukkan bahwa ke-empat subjek telah menjadi flourisher dengan menunjukkan kelima aspek PERMA flourishing dalam hidup mereka. Aspek yang pertama adalah keempat subjek telah mampu menunjukkan emosi yang positif seperti kebahagiaan, kedamaian, rasa bersyukur, dan kesabaran. Mereka juga lebih melekat dengan pekerjaannya hingga tidak ingin menunda pekerjaan. Hubungan mereka juga telah lebih baik dengan keluarga dan orang sekitar terbukti dengan kurangnya perilaku agresif (KDRT), terlibat dalam kerja bakti dan tidak lagi membuat keributan. Mereka juga memaknai hidup dengan fokus melakukan hal yang lebih positif seperti mempererat hubungan pribadi dengan Tuhan dan juga lingkungan sekitar. Adapun pencapaian yang membanggakan dalam hidup mereka yaitu memutuskan untuk berhenti menjadi pecandu alkohol. Penerapan flourishing berdasarkan PERMA sudah cukup konsisten dan intense dalam diri subjek serta keluarga maka solusi untuk ke-empat subjek yaitu tetap mengontrol diri dengan tetap menggandalkan dukungan sosial dan memperkuat aktivitas religious. Disisi lain, dampak residu negatif dari mantan pecandu alkohol terlihat pada kondisi fisik subjek yang mudah lelah, dan sakit pada bagian tubuh tertentu.

Abstract

It is difficult choice for an alcoholic to quit their dependency on this psychoactive substance. Therefore, in this study using a positive psychological approach as a basis for analyzing the flourishing of former alcoholics in Sumlili Village. Qualitative methods with non-participant observation and semi-structured interviews were conducted on 4 adult subjects who had stopped consuming alcohol for 2 years, 4 years, 5 years, and 9 years. Triangulation is done by observing and interviewing the subject's family. The research sampling technique used purposive sampling. The results showed that subjects became flourisher by showing the five aspects of flourishing in their lives. The first aspect is that the subjects show positive emotions such as happiness, peace, gratitude, and patience. They are also more attached to their work so they not procrastinate it. A better relation- 
ship with family, and others showed by lack of aggressive behavior (domestic violence), engaging in community service, and no longer creating chaos. They also interpret life with doing more positive things such as strengthening personal relationships with God and the surrounding environment. The proud achievement in their lives is decided by stop being an alcoholic. The application of flourishing based on PERMA is quite consistent and intense in the subject and the family, the solution for the subjects is to keep controlling themselves while still relying on social support and strengthening religious activities. In contrary, negative residual effects of former alcoholics seen in the physical condition of subjects who are easily tired, and sick in certain body parts.

\section{PENDAHULUAN}

Penyalahgunaan zat-zat terlarang khususnya alkohol tidak hanya terjadi di kotakota besar namun tersebar hingga daerah pedesaan yang merambah pada remaja dan juga orang dewasa. Minuman beralkohol adalah minuman yang mengandung etanol. Etanol adalah bahan psikoaktif yang akan menyebabkan penurunan kesadaran bagi seseorang yang mengkonsumsinya (Nurulina, 2013). Pecandu alkohol adalah istilah yang digunakan pada orang yang menggunakan dan mengkonsumsi alkohol dalam jangka waktu lama. Dengan konsumsi minuman beralkohol yang berlebihan membuat seseorang memiliki potensi untuk menurunkan kualitas hidupnya, yang terlihat dari perilaku menyimpang seperti perkelahian, pencurian dan perbuatan kriminal serta melakukan hubungan seks secara bebas (Prabowo \& Pratisti, 2017).

Surat kabar online pikiranrakyat.com (Irfan, 2017) menyampaikan hasil riset yang dilakukan oleh Lembaga Kajian dan Pengembangan Sumber Daya Manusia (Lakpesdam) Pengurus Wilayah Nahdlatul Ulama (PWNU) DKI Jakarta bersama Pusat Penguatan Otonomi Daerah (PPOD), yang menunjukan bahwa penggunaan minuman berarkohol oplosan cenderung meningkat. Kondisi ini terjadi khususnya pada subjek anak di bawah umur dengan angka yang cukup tinggi yakni sekitar 65,3 persen. Riset ini melibatkan 327 responden remaja berusia 12 sampai 21 tahun di wilayah Jakarta, Bogor, Depok, Tangerang, dan Bekasi. Berdasarkan hasil pengamatan penulis, situasi yang hampir mirip ini juga terjadi di Provinsi
NTT (Nusa Tenggara Timur) baik pada remaja maupun orang dewasa. Penelitian Lette, Ratnawati, \& Swasti (2016) menyampaikan bahwa di Provinsi NTT terdapat sejenis minuman fermentasi lokal beralkohol, yaitu: laru dan sopi. Sopi adalah nama lokal untuk minuman khas yang diproduksi secara turun temurun oleh masyarakat yang ada di berbagai pulau di NTT maupun Maluku. Meskipun keberadaannya ilegal, minuman tersebut telah beredar luas, mudah didapat, walaupun penjualannya dilakukan secara sembunyi-sembunyi. Dalam keseharian, sopi selalu hadir di tengah masyarakat NTT, khususnya pada acara besar keluarga dan adat.

$$
\text { Data dari CNN Indonesia (2018) }
$$
disebutkan laporan dari World Health Organization (WHO) menunjukan sebanyak 3 juta orang di dunia meninggal akibat konsumsi alkohol pada tahun 2016. Angka itu setara dengan 1 dari 20 kematian di dunia disebabkan oleh konsumsi alkohol, lebih dari 75 persen kematian akibat alkohol terjadi pada pria. Di Indonesia pada tahun 2014 mengalami peningkatan, Badan Narkotika Nasional (BNN) memperkirakan ada 3,2 juta orang (1,5\% dari total populasi) di Indonesia mempunyai riwayat penggunaan NAPZA diantaranya $46 \%$ adalah perilaku minum alkohol (dalam Maula \& Yuniastuti, 2017). Sebagai tambahan, data dari BPS (Badan Pusat Statistik) dalam tiga tahun berturut-turut dari 2015-2018 menemukan bahwa konsumsi alkohol oleh penduduk umur lebih dari 15 tahun mengalami peningkatan pada setiap tahunnya. Lalu BPS menemukan bahwa daerah pedesaan memiliki angka konsumsi alkohol yang lebih tinggi dari daerah 
perkotaaan. Berdasarkan sumber ini, menjadi salah satu pertimbangan dasar bagi penulis dalam menentukan lokasi penelitian ini yang terletak di pedesaan dan berfokus pada Desa Sumlili, Kecamatan Kupang Barat.

Berkaitan dengan dampak dari minuman alkohol, DSM IV (dalam Prabowo \& Pratisti, 2017) dijelaskan bahwa penggunaan minuman beralkohol dalam jangka pendek dapat mengakibatkan peningkatan emosi negatif, mengganggu proses berpikir kompleks, koordinasi motorik, dan kemampuan bicara, serta penglihatan melemah. Dosis alkohol bersifat sedatif karena dapat menimbulkan rasa tenang, dan kantuk yang bisa berakibat pada kematian. Minuman beralkohol yang dikonsumsi dalam jangka waktu lama berakibat pada kerusakan biologis dan kemunduran psikologis. Secara biologis, minuman beralkohol memberikan efek negatif bagi hampir semua jaringan dan organ tubuh, yang menyebabkan malnutrisi kronis karena penghambat pencernaan makanan dan penyerapan vitamin sedangkan secara psikologis, minuman beralkohol memberikan efek dimana emosi yang tidak bisa dikontrol dan juga insomnia. Dampak selanjutnya bisa menyebabkan sindrom amnestik, sirosis hati, munculnya perubahan fisiologis, kerusakan sel-sel syaraf otak dan mengurangi efektifitas sistem imun.

Terlepas dari banyaknya peminum alkohol yang ada di masyarakat, terdapat pula para pelaku yang telah sungguh-sungguh berhenti mengonsumsi alkohol yang disebut dengan mantan pecandu alkohol. Mantan pecandu alkohol adalah individu yang pernah menjadi pecandu alkohol, yang mana individu tersebut sekarang telah berhenti untuk tidak lagi mengkonsumsi alkohol karena alasan tertentu. Orang yang telah berhenti mengonsumsi alkohol secara total memiliki kecenderungan menunjukkan sisi positif dari dirinya karena telah melepaskan diri dari pengaruh alkohol. Dalam penelitian ini, penulis menggunakan pendekatan psikologi positif untuk menganalisa subjek yang sudah menjadi mantan pecandu alkohol.
Seligman and Csikszentmihalyi (dalam Aulia, 2015) mendefinisikan psikologi positif sebagai studi ilmiah tentang fungsi manusia yang positif dan berkembang pada beberapa tingkat yang mencakup biologi, personal, relasional, kelembagaan, budaya, dan dimensi kehidupan secara global. Tujuan dari pendekatan ini adalah mengidentifikasi, meningkatkan kekuatan, dan kebajikan manusia yang membuatnya dapat hidup dengan layak lalu memungkinkan individu dan masyarakat untuk berkembang lebih positif dan berkualitas. Ketika seseorang telah mempunyai kualitas hidup yang baik dapat dianggap bahwa individu tersebut dapat merasakan kebahagiaan dalam hidupnya. Yuspendi, Handojo, \& Handayani (2017) mengatakan bahwa kebahagiaan autentik diperoleh dari realisasi virtue dalam kehidupan. Kebahagiaan autentik akan ditandai oleh flourishing yaitu berkembang-penuhnya pribadi seseorang karena telah menjalani hidup yang baik. Konsep flourishing sangat mirip dengan konsep aktualisasi yang merupakan salah satu konsep psikologi humanistik, tetapi bedanya konsep flourishing dapat terukur. Individu yang mencapai hidup flourishing ditandai dengan kualitas emosi yang baik dan seimbang, relasi yang positif dengan orang lain, hidup yang bermakna dan memiliki tujuan baik bagi sesama, memiliki autonomi serta kualitas dan kuantitas dalam pencapaian prestasi dalam kehidupan individu.

Keyes (dalam Schotanus-dijkstra \& Pieterse, 2016) melakukan studi yang komprehensif tentang flourishing. Ia mengatakan bahwa individu yang memiliki flourishing dalam dirinya disebut dengan flourisher. Karakteristiknya yaitu memiliki level kontrol emosi, sosial, dan kesejahteraan psikologis yang tinggi. Sedangkan sisi sebaliknya dari flourishing adalah languishing (keadaan merana, sengsara, tidak bahagia). Lalu individu yang berada posisi tengah atau sedang disebut dengan kesehatan mental moderat. Adapun yang dimaksud dengan flourishing yaitu tingkatan paling tinggi dan akhir dalam kondisi 
psikologis individu dan merupakan konsep utama dalam penelitian tentang psikologi positif. Individu yang mencapai hidup flourishing ditandai dengan kesehatan mental yang baik karena kemampuan individu dalam mengolah stres dengan baik. Flourishing merupakan pengalaman hidup yang berjalan dengan baik dan juga merupakan kombinasi dari perasaan baik (good feeling) dan berfungsi secara efektif. Flourishing sinonim dari level kesejahteraan mental yang tinggi dan melambangkan kesehatan mental (Effendy, 2016).

Demikian juga hasil penelitian dari Effendy \& Subandriyo (2017) seseorang dikatakan mengalami flourishing apabila ia mengalami 5 pilar PERMA yaitu Positive emotion (emosi yang positif), Engagement (kelekatan), positive Relationship (hubungan yang positif), Meaning (hidup yang bermakna), Accomplishment (pencapaian/prestasi) dengan kategori tinggi. Sistematik review dari Parker, Banbury, \& Chandler (2018) menyatakan bahwa adanya peningkatan ketertarikan untuk meneliti tentang pendekatan positif psikologi pada kasus kecanduan alkohol dan obat-obatan. Mereka juga mengindikasikan adanya beberapa bukti korelasi negatif antara flourishing dan kadar penggunaan alkohol, artinya semakin kurang intensitas konsumsi alkohol maka kondisi flourishing akan meningkat dan berlaku sebaliknya. Penelitian ini juga menyarankan bahwa flourishing merupakan esensi penting dari proses pengukuran kesehatan mental secara menyeluruh, assesmen gangguan penggunaan zat berbahaya termasuk alkohol, dan menjadi tujuan penanganan yang berarti dalam mengembangkan proses pemulihan.

Melihat begitu bermaknanya peran flourishing dalam kasus individu yang pernah kecanduan alkohol serta membandingkan dengan fenomena di pedesaan Kota Kupang yang masih banyak masyarakat yang kecanduan alkohol (jenis tradisional dan modern) dan sulit bagi mereka untuk berhenti dari kecanduan tersebut, maka sangat penting untuk meneliti dan menggali proses psikologis yang terjadi dalam diri individu yang berhasil mempertahankan diri untuk berhenti dari konsumsi minuman alkohol. Kesenjangan fenomena di masyarakat yang mana diantara banyaknya orang yang masih menjadi pecandu alkohol, namun ada juga sedikit individu yang berhasil untuk berhenti menjadi pecandu alkohol. Karena itu, penulis menentukan tujuan penelitian ini untuk mengetahui, memahami, dan menganalisa flourishing pecandu alcohol yang sudah berhenti konsumsi alkohol secara konsisten lebih dari dua tahun, sehingga penulis dapat melihat berbagai perubahan yang terjadi pada subyek ketika sudah berhenti mengonsumsi alkohol.

\section{METODE}

Metode yang digunakan dalam penelitian ini adalah metode kualitatif. Metode penelitian kualitatif adalah metode penelitian yang digunakan untuk meneliti pada kondisi obyek yang alamiah, peneliti ditempatkan dalam posisi yang penting sebagai instrumen kunci. Obyek dalam penelitian kualitatif adalah obyek yang alamiah atau natural setting, sehingga metode penelitian ini sering disebut sebagai metode naturalistic. Obyek yang alamiah adalah obyek yang apa adanya, tidak dimanipulasi oleh peneliti sehingga kondisi pada saat peneliti awal bertemu obyek, setelah bertemu obyek dan setelah selesai dari proses meneliki obyek relatif tidak mengalami perubahan (Sugiono, 2015).

Teknik pengumpulan data merupakan langkah yang paling strategis dalam penelitian, karena tujuan utama dari penelitian adalah mendapatkan data. Pengumpulan data dapat dilakukan dalam berbagai setting, berbagai sumber, dan berbagai cara. Dalam penelitian kualitatif, pengumpulan data dilakukan dengan beberapa teknik yaitu observasi dan wawancara (Alsa, 2014). Tahap persiapan penulis adalah melakukan pra penelitian dengan melakukan observasi dan wawancara awal dengan subyek. Lalu, proses pengambilan data lebih lanjut dan mendalam menggunakan teknik observasi non partisipan dan wawancara semi terstruktur pada subjek dan juga orang terdekat subjek. Pengambilan 
data dimulai dari bulan April 2019 - Januari 2020. Dalam penelitian ini, yang menjadi latar tempat adalah Desa Sumlili, Kecamatan Kupang Barat, Kabupaten Kupang. Selain berdasarkan data bahwa di daerah pedesaan, angka pecandu alkohol lebih tinggi dari perkotaan, ada beberapa alasan khusus dari peneliti memilih lokasi ini yaitu kedekatan peneliti dengan masyarakat dan subjeknya sehingga mempermudah untuk menjalin rapport dan menggali data. Alasan kedua yaitu berdasarkan hasil observasi peneliti ketika berada di desa Sumlili bahwa ada kebiasaan yang terlihat masyarakat cenderung suka berkumpul sambil meminum alkohol baik ketika ada perayaan atau hanya perkumpulan informal saja, namun disisi lain ada juga empat orang subjek yang terlihat konsisten untuk berhenti menjadi pecandu alkohol lebih dari dua tahun.

Teknik sampling yang digunakan yaitu purposive sampling. Menurut Sugiono (2015), purposive sampling adalah teknik pengambilan sampel sumber data dengan pertimbangan tertentu. Sumber datanya adalah 4 subjek mantan pecandu alkohol yang telah berhenti selama 2, 4, 5, dan 9 tahun. Kriteria subjek adalah pecandu alkohol yang sudah bisa berhenti mengonsumsi alkohol minimal dua tahun, berdomisili di Desa Sumlili, dan bersedia menjadi subjek penelitian.

Tahapan analisa data penelitian ini dilakukan berdasarkan proses mencari dan menyusun secara sistimatis data yang diperoleh dari hasil wawancara, catatan lapangan, dan dokumentasi, dengan cara mengorganisasi data kedalam kategori, menjabarkan kedalam unit-unit, melakukan sintesa, menyusun kedalam pola, memilih mana yang penting dan yang akan dipelajari, dan membuat kesimpulan sehingga mudah dipahami oleh diri sendiri dan orang lain (Sugiono, 2015). Analisis data terdiri dari data reduction, data display, dan conclusion drawing/ verification yang dilakukan secara interaktif dan berlangsung secara terus menerus sampai tuntas, sehingga datanya mencapai jenuh (Satori \& Komariah, 2011).
Dalam penelitian ini, triangulasi yang dilakukan dengan cara membandingkan data hasil wawancara maupun observasi antara subjek penelitian dengan orang-orang yang dekat dengan subjek seperti orangtua kandung, pasangan (istri), dan anak kandung. Lalu membandingkan data pada waktu yang berbeda yaitu pada waktu subjek menjadi pecandu dan setelah subjek berhenti menjadi pecandu alkohol. Proses pembandingan ini dilakukan untuk mengecek kebenaran maupun untuk melihat kesesuaian antara satu sama lain sehingga didapat keabsahan data.

\section{HASIL}

Dari 4 subjek utama penelitian dan didukung dengan subjek pelengkap yang merupakan orang terdekat dari setiap subjek, diperoleh berbagai tema temuan yang menunjukan kondisi flourishing dan proses dari setiap subjek dari seorang pecandu alcohol kemudian men-

Tabel 1. Karakteristik subjek penelitian

\begin{tabular}{|c|c|c|c|c|}
\hline \multirow{2}{*}{$\begin{array}{c}\text { Karak- } \\
\text { teristik } \\
\text { subjek }\end{array}$} & \multicolumn{4}{|c|}{ Subjek penelitian (Inisial) } \\
\hline & $\begin{array}{c}1 \\
(\mathbf{S . N})\end{array}$ & $\begin{array}{c}2 \\
\text { (D.M) }\end{array}$ & $\begin{array}{c}3 \\
\text { (C.S) }\end{array}$ & $\begin{array}{c}4 \\
\text { (Y.H) }\end{array}$ \\
\hline Usia & $\begin{array}{c}29 \\
\text { tahun }\end{array}$ & $\begin{array}{c}49 \\
\text { tahun }\end{array}$ & 33 tahun & 56 tahun \\
\hline $\begin{array}{l}\text { Jenis } \\
\text { kelamin }\end{array}$ & Laki-laki & Laki-laki & Laki-laki & Laki-laki \\
\hline $\begin{array}{l}\text { Peker- } \\
\text { jaan }\end{array}$ & $\begin{array}{l}\text { Wiras- } \\
\text { wasta di } \\
\text { bidang } \\
\text { pari- } \\
\text { wisata }\end{array}$ & $\begin{array}{l}\text { Buruh } \\
\text { harian }\end{array}$ & Supir & Petani \\
\hline Status & $\begin{array}{l}\text { Belum } \\
\text { menikah }\end{array}$ & $\begin{array}{l}\text { Sudah } \\
\text { menikah } \\
\text { ( } 1 \text { istri, } 4 \\
\text { anak) }\end{array}$ & $\begin{array}{l}\text { Sudah } \\
\text { menikah } \\
\text { (1 istri, } 4 \\
\text { anak) }\end{array}$ & $\begin{array}{l}\text { Sudah } \\
\text { menikah } \\
\text { (1 istri, } 3 \\
\text { anak) }\end{array}$ \\
\hline $\begin{array}{l}\text { Usia } \\
\text { menjadi } \\
\text { pecandu }\end{array}$ & 15 tahun & 18 tahun & $\begin{array}{l}16 / 17 \\
\text { tahun }\end{array}$ & 36 tahun \\
\hline $\begin{array}{l}\text { Durasi } \\
\text { berhenti } \\
\text { alkohol }\end{array}$ & $\begin{array}{l}\text { Dari } \\
\text { tahun } \\
2017 \text { (2- } \\
3 \text { tahun) }\end{array}$ & $\begin{array}{l}\text { Dari ta- } \\
\text { hun } 2015 \\
\text { ( } 4-5 \text { ta- } \\
\text { hun) }\end{array}$ & $\begin{array}{l}\text { Dari ta- } \\
\text { hun } 2014 \\
\text { (5-6 ta- } \\
\text { hun) }\end{array}$ & $\begin{array}{l}\text { Dari } \\
\text { tahun } \\
2010 \\
(9-10 \\
\text { tahun) }\end{array}$ \\
\hline Agama & $\begin{array}{l}\text { Kristen } \\
\text { protestan }\end{array}$ & $\begin{array}{l}\text { Kristen } \\
\text { protestan }\end{array}$ & $\begin{array}{l}\text { Kristen } \\
\text { protestan }\end{array}$ & $\begin{array}{l}\text { Kristen } \\
\text { protestan }\end{array}$ \\
\hline $\begin{array}{l}\text { Triangu- } \\
\text { lasi }\end{array}$ & $\begin{array}{l}\text { Ibu } \\
\text { subjek }\end{array}$ & $\begin{array}{l}\text { Istri dan } \\
\text { anak }\end{array}$ & $\begin{array}{l}\text { Istri dan } \\
\text { anak }\end{array}$ & $\begin{array}{l}\text { Istri dan } \\
\text { anak }\end{array}$ \\
\hline
\end{tabular}


jadi mantan pecandu yang betul-betul pulih dan dapat terlepas dari ketergantungannya terhadap alkohol. Berikut ini, penulis menjabarkan lima tema temuan utama yaitu karakteristik subjek penelitian, perbandingan kondisi subjek ketika menjadi pecandu alkohol dan berhenti menjadi pecandu, aspek-aspek flourishing pada mantan pecandu alkohol, faktor-faktor yang mendukung kondisi flourishing pada subjek penelitian, dan dampak positif pada lingkungan terdekat subjek.

\section{Karakteristik subjek penelitian}

Dari tabel 1. dijelaskan tentang berbagai identitas utama dari setiap subjek penelitian seperti usia, jenis kelamin, pekerjaan, status pernikahan, usia ketika pertama kali menjadi pecandu alkohol, durasi waktu setelah menjadi mantan pecandu, agama, dan triangulasi dilakukan pada pihak-pihak terdekat.

\section{Kondisi Subjek Ketika Menjadi Pecandu Alcohol dan Alasan Berhenti Menjadi Pe- candu}

Pada tabel 2. menujukan kondisi setiap subjek dari awal proses tertarik dengan alkohol hingga mengambil keputusan untuk berhenti mengonsumsi alkohol. Dari keempat subjek diketahui bahwa faktor yang memicu tertarik mencoba alkohol yaitu keinginan untuk mencoba dari dalam diri dan pengaruh lingkungan membuat setiap subjek cukup lama nyaman menjadi pecandu alcohol. Dengan alasan yang berbeda-beda namun dapat disimpulkan dalam satu kategori yang sama yaitu kesadaran dari diri sendiri. Tingkat ketergantungan setiap subjek pada alcohol juga sama yaitu pada level tinggi, karena hampir setiap hari mengonsumsi dan berada hingga kondisi mabuk. Jenis alkohol yang dikonsumsi yaitu alkohol tradisional khas NTT bernama sopi. Sopi ini memiliki harga yang lebih murah dan lebih mudah didapatkan karena dibuat secara lokal dirumahrumah masyarakat. Ketika ada acara-acara keluarga, selepas acara selesai ketika duduk dan berkomunikasi bersama-sama biasanya sopi mudah ditemukan dan disediakan gratis oleh bandar (orang yang dengan sukarela membeli dan membagikan untuk diminum bersama).
Tabel 2. tabel kondisi subjek

\begin{tabular}{|c|c|c|c|c|}
\hline \multirow{2}{*}{$\begin{array}{l}\text { Kondisi } \\
\text { subjek }\end{array}$} & \multicolumn{4}{|c|}{ Subjek penelitian } \\
\hline & 1 (S.N) & 2 (D.M) & 3 (C.S) & 4 (Y.H) \\
\hline $\begin{array}{l}\text { Awal } \\
\text { pemicu } \\
\text { menjadi } \\
\text { pecandu }\end{array}$ & $\begin{array}{l}\text { Ada } \\
\text { keingi- } \\
\text { nan da- } \\
\text { lam diri } \\
\text { untuk } \\
\text { mencoba } \\
\text { dan dita- } \\
\text { warkan } \\
\text { ketika } \\
\text { ada acara } \\
\text { keluarga }\end{array}$ & $\begin{array}{l}\text { Pengaruh } \\
\text { tawaran } \\
\text { dan } \\
\text { ajakan } \\
\text { dari te- } \\
\text { man seba- } \\
\text { ya. Ia juga } \\
\text { berangga- } \\
\text { pan mem- } \\
\text { inum } \\
\text { alkohol } \\
\text { dapat } \\
\text { mengu- } \\
\text { rangi ma- } \\
\text { salahnya } \\
\text { dan den- } \\
\text { dam } \\
\text { dengan } \\
\text { ayah }\end{array}$ & $\begin{array}{l}\text { Hanya } \\
\text { men- } \\
\text { coba } \\
\text { lalu } \\
\text { terbi- } \\
\text { asa } \\
\text { dan } \\
\text { juga } \\
\text { karena } \\
\text { pengar } \\
\text { uh } \\
\text { per- } \\
\text { gaulan } \\
\text { dengan } \\
\text { para } \\
\text { pemi- } \\
\text { num } \\
\text { alcohol }\end{array}$ & $\begin{array}{l}\text { Hanya } \\
\text { menco- } \\
\text { ba, } \\
\text { meniru } \\
\text { teman, } \\
\text { dan } \\
\text { merasa } \\
\text { alcohol } \\
\text { sebagai } \\
\text { sarana } \\
\text { mem- } \\
\text { pererat } \\
\text { komu- } \\
\text { nikasi } \\
\text { dengan } \\
\text { teman } \\
\text { per- } \\
\text { gaulan }\end{array}$ \\
\hline $\begin{array}{l}\text { Alasan } \\
\text { berhenti } \\
\text { dari pe- } \\
\text { candu }\end{array}$ & $\begin{array}{l}\text { Menderit } \\
\text { a sakit } \\
\text { lambung } \\
\text { yang } \\
\text { parah } \\
\text { hingga } \\
\text { mendapa } \\
\text { tkan } \\
\text { perawa- } \\
\text { tan inten- } \\
\text { sif di } \\
\text { rumah } \\
\text { sakit }\end{array}$ & $\begin{array}{l}\text { Merasa } \\
\text { kebiasaan } \\
\text { mabuk } \\
\text { setiap } \\
\text { harinya } \\
\text { meng- } \\
\text { hambat ia } \\
\text { mendapat- } \\
\text { kan } \\
\text { pekerjaan }\end{array}$ & $\begin{array}{l}\text { Dari } \\
\text { keingi- } \\
\text { nan } \\
\text { diri } \\
\text { sendiri } \\
\text { karena } \\
\text { me- } \\
\text { rasaka } \\
\text { n ban- } \\
\text { yak } \\
\text { efek } \\
\text { negatif } \\
\text { yang } \\
\text { diala- } \\
\text { mi }\end{array}$ & $\begin{array}{l}\text { Ia ser- } \\
\text { ing } \\
\text { men- } \\
\text { galami } \\
\text { mimpi } \\
\text { buruk } \\
\text { misal- } \\
\text { nya ia } \\
\text { mening } \\
\text { gal, } \\
\text { keluar- } \\
\text { ga } \\
\text { mening } \\
\text { gal, dan } \\
\text { kecel- } \\
\text { akaan. } \\
\text { Hal itu } \\
\text { mem- } \\
\text { buat ia } \\
\text { kesu- } \\
\text { litan } \\
\text { tidur } \\
\text { hingga } \\
\text { pagi } \\
\text { hari. }\end{array}$ \\
\hline $\begin{array}{l}\text { Tingkat } \\
\text { ketergan- } \\
\text { tungan }\end{array}$ & $\begin{array}{l}\text { Setiap } \\
\text { hari pasti } \\
\text { ia selalu } \\
\text { mengons } \\
\text { umsi } \\
\text { alkohol }\end{array}$ & $\begin{array}{l}\text { Ia selalu } \\
\text { meng- } \\
\text { onsumsi } \\
\text { alkohol } \\
\text { bersama } \\
\text { dengan } \\
\text { komunitas } \\
\text { pemabuk }\end{array}$ & $\begin{array}{l}\text { Rutin } \\
\text { dan } \\
\text { minum } \\
\text { alko- } \\
\text { hol } \\
\text { hingga } \\
\text { mabuk }\end{array}$ & $\begin{array}{l}\text { Dua } \\
\text { botol } \\
\text { per hari } \\
\text { hingga } \\
\text { mabuk }\end{array}$ \\
\hline
\end{tabular}




\begin{tabular}{|c|c|c|c|c|}
\hline $\begin{array}{l}\text { Jenis } \\
\text { alkohol }\end{array}$ & $\begin{array}{l}\text { Alkohol } \\
\text { tradision- } \\
\text { al (Sopi) }\end{array}$ & $\begin{array}{l}\text { Alkohol } \\
\text { tradision- } \\
\text { al (Sopi) }\end{array}$ & $\begin{array}{l}\text { Alko- } \\
\text { hol } \\
\text { tradi- } \\
\text { sional } \\
\text { (Sopi) }\end{array}$ & $\begin{array}{l}\text { Alko- } \\
\text { hol } \\
\text { tradi- } \\
\text { sional } \\
\text { (Sopi) }\end{array}$ \\
\hline
\end{tabular}

\section{Aspek-Aspek Flourishing Pada Mantan Pecandu Alkohol}

Berdasarkan pendekatan psikologi positif dari Seligman khususnya tentang flourishing terdiri atas lima aspek utama yaitu PERMA, yang terdiri atas Positive emotion (emosi yang positif), Engagement (kelekatan), positive Relationship (hubungan yang positif), Meaning (hidup yang bermakna), Accomplishment (pencapaian/prestasi). Setiap aspek ini dikaitkan dengan data observasi dan wawancara dari kondisi masing-masing subjek, khususnya secara mendalam setelah subjek menjadi mantan pecandu alkohol.

Aspek pertama berkaitan dengan emosi yang positif, dari hasil wawancara dan observasi terlihat bahwa subjek I, II, III dan IV telah mampu mengontrol emosi dengan baik meskipun pendapatnya dikritik dan juga kemauannya tidak selalu diikuti. Ke-empat subjek menunjukkan emosi yang positif dalam kesehariannya yaitu merasa sukacita, bahagia, senang dan juga sering tersenyum ke semua orang. Hal ini dirasakan oleh subjek karena masing-masing subjek merasa dicintai oleh keluarganya, mampu menjalankan tugas sebagai kepala keluarga (orangtua), mampu berdamai dengan ayah, dan menjadi lebih taat pada Tuhan. Emosi positif berupa rasa bersyukur dan tidak mudah mengeluh memberikan dampak pada kondisi spiritual setiap subjek yang jadi lebih taat pada Tuhan dan rajin melibatkan diri dalam kegiatan rutin kegerejaan. Selain itu, perasaan damai dan mudah memaafkan dialami oleh setiap subjek karena sudah berkurangnya konflik dan agresifitas yang terjadi dalam keluarga. Kondisi emosi setiap subjek ketika masih menjadi pecandu tergolong sangat negatif yang terlihat dari emosi yang mudah marah, menyimpan dendam, hingga menunjukan perilaku sangat agresif pada orangtua, istri, dan anak.

Berkaitan dengan aspek engagement (kelekatan), pada saat masih menjadi pecandu mereka berempat berada pada kondisi yang mirip yaitu kurang memiliki kelekatan dengan suatu aktivitas atau pekerjaan. Setiap hari, mereka lebih sering berkumpul dengan para peminum saja hingga mabuk, lalu menjadi malas bekerja dan melalaikan pekerjaan yang ada. Setelah menjadi mantan pecandu, keempat subjek mulai melekat dan fokus pada pekerjaan mereka masing-masing, walaupun harus bekerja wiraswasta, tidak menetap (harian saja) sebagai buruh ataupun petani. Bahkan mereka mengaku bahwa jika tidak dalam sakit maka mereka selalu menyelesaikan pekerjaan tanpa ingin menunda. Mereka juga merasakan kepuasan dan kebahagiaan karena setiap pekerjaan yang mereka kerjakan telah membuahkan hasil yng memuaskan bagi diri mereka sendiri dan juga bagi keluarga untuk dinikmati bersama.

Aspek ketiga berkaitan dengan hubungan yang positif, data menunjukkan bahwa ketika mereka masih tergantung dengan alkohol, saat sudah mabuk mereka sering menimbulkan keributan dalam keluarga, tentangga bahkan ketika ada kegiatan ibadah, sehingga relasi menjadi buruk dan renggang. Karena seringnya subjek 2, 3, dan 4 melakukan KDRT pada istri dan anak hingga istri ada keinginan berpisah dan anak juga memiliki perasaan benci dengan ayahnya. Setelah berhenti dari konsumsi alkohol, keempat subjek lebih mampu membangun relasi yang baik dan akrab dengan keluarga dan lingkungan sekitar. Subjek tidak lagi melakukan KDRT dan berdamai dengan seluruh anggota keluarga. Mereka juga sadar bahwa hidup saling membutuhkan sehingga tolong-menolong adalah hal yang wajib dilakukan sesama manusia. Karena itu, subjek 3 meluangkan waktu berkomunikasi baik dengan tetangganya. Subjek 4 lebih aktif dalam kegiatan ibadah dan gereja, dan tidak mengganggu proses ibadah lagi.

Aspek keempat tentang hidup yang bermakna. Ke-empat subjek ketika fokus hidupnya masih pada alkohol saja, hidup terasa hampa dan tidak bermakna. Bahkan kalau direfleksikan kembali pada masa menjadi pecandu itu, ada penyesalan yang kuat dirasa- 
kan oleh setiap subjek. Setiap subjek menyadari bahwa bergantung pada minuman alkohol adalah suatu hal yang sia-sia, harusnya hidup ini dijalani dengan hal-hal positif dan menjauhi diri dari hal-hal negatif seperti mabuk dan perkelahian. Setiap subjek ketika menyadari penuh arti dan bermaknanya hidup yang telah diberikan Tuhan secara gratis ini serta menyadari perhatian dari keluarga, hal ini menjadi alasan kuat yang mendukung untuk berhenti menjadi pecandu, lebih menjaga kesehatan, dan merubah kehidupan menjadi lebih positif dalam berbagai aspek kehidupan.

Aspek yang terakhir yaitu pencapaian atau prestasi dalam hidup. Ke-empat subjek sama-sama menyadari bahwa dengan mengambil keputusan untuk berhenti menjadi pecandu dan memiliki kehidupan yang lebih dekat pada Tuhan adalah suatu pencapaian hidup yang membanggakan dan kemudian mendatangkan berbagai prestasi lainnya sebagai seorang suami, anak, dan anggota keluarga. Bagi subjek 1 dengan menjaga kesehatan dan bisa bekerja semaksimal mungkin membantu orangtua adalah pencapaiannya dalam hidup. Subjek 2 beranggapan bahwa pencapaian terbesar dalam hidupnya adalah hidup berdamai dengan ayahnya. Ia berkata bahwa ia memilih lebih dahulu mengalah, tidak berlarut-larut dalam dendam, dan memperbaiki kembali hubungan yang retak dengan kedua orang tuanya untuk kebaikan bersama. Subjek 3 yaitu dengan menjadi seorang kepala keluarga yang bertanggungjawab penuh untuk memberikan nafkah serta kasih sayang kepada keluarganya. Ia juga ingin menyekolakan anak-anaknya hingga ke jenjang yang sangat tinggi. Lalu subjek 4 menyatakan bahwa sebuah pencapaian dalam hidup ketika setiap pekerjaannya selalu menbuahkan hasil bahkan ia dapat membeli sesuatu yang ia inginkan misalnya membeli tanah sendiri dan motor air guna memudahkannya dalam bekerja sebagai petani.

\section{Perubahan Positif dari Flourishing Subjek Penelitian pada Lingkungan Terdekat}

Berdasarkan data triangulasi pada orangorang terdekat (ibu, istri, dan anak) setiap subjek didapatkan data bahwa subjek menunjukan perubahan positif yang signifikan dibandingkan masih menjadi pecandu. Menurut orang-orang terdekat setiap subjek, ketika subjek menjadi pecandu hidup mereka hanya dikendalikan oleh alkohol sehingga banyak hal negatif yang dilakukan. Bahkan pada subjek 1, pernah ada niatan dari keluarga untuk melaporkannya ke pihak kepolisian karena perilaku negatif yang dilakukan begitu meresahkan. Pada subjek 4, istri sudah melaporkannya pada kepolisian karena tindakan KDRT dan suami sudah sempat ditahan di penjara. Tapi pada akhirnya istrinya memberikan kesempatan lagi untuk suaminya bisa bebas dan berubah. Setelah keluar dari penjara, subjek kemudian mengambil keputusan untuk berhenti menjadi pecandu.

Setelah mengambil keputusan berhenti konsumsi alkohol, ke-empat subjek menunjukan perubahan positif yang mirip seperti tidak lagi bertemu dan berkumpul dengan teman-teman pemabuknya, sebaliknya mereka mampu menolak jika ada yang menawarkan untuk minum, mampu membangun relasi positif dengan kelompok masyarakat yang lebih positif seperti di gereja dan kegiatan kerja bakti. Setiap subjek juga tidak lagi melakukan tindakan agresif atau tindakan KDRT, sebaliknya karena mereka sudah merasa lebih bahagia, damai, dan bersyukur hingga akhirnya terlihat pada perilaku seharihari yang lebih ramah dan tersenyum pada orang-orang terdekat dan sekitar. Bahkan anak subjek mengatakan bahwa jika ayah meminta mengambilkan suatu barang dan mereka sedikit lama memberikannya, maka ayahnya langsung marah bahkan memukul. Anak-anak subjek hingga merasa benci pada ayahnya. Setelah berhenti menjadi pecandu, ayah mereka lebih banyak bercanda di dalam rumah, sering nonton televisi bersama, bercerita tentang sekolah anak-anak, tentang pekerjaan dan tentang hal-hal positif lainnya.

Perubahan positif selanjutnya terlihat pada rutinitas dan aktivitas sehari-hari subjek. Mereka yang sebelumnya setiap hari hanya 
fokus untuk minum alkohol hingga mabuk, lalu menjadi malas dan melupakan untuk bekerja. Setelah berhenti menjadi pecandu, mereka lebih rajin dalam bekerja, tidak menunda-nunda kerjaan, dan tidak memilihmilih jenis pekerjaan. Karena ini, keluarga juga merasakan bahwa berbagai kebutuhan sehari-hari lebih mampu dipenuhi dan permasalahan ekonomi juga dapat diatasi. Lalu perubahan secara spiritual juga sangat nampak pada diri setiap subjek yang sudah lebih aktif dalam kegiatan rohani, lebih mampu memaknai dan mensyukuri hidup ini semua karena Tuhan.

Dari data triangulasi dapat disimpulkan bahwa perubahan karakter dari setiap subjek yaitu jujur, peduli, disiplin, tanggungjawab, kerja keras, dan sederhana. Kemudian karakter positif ini menjadi model untuk setiap anak subjek belajar meniru.

\section{Dampak negatif (residu) dari alkohol pada subjek penelitian}

Berdasarkan hasil wawancara pada subjek dan anggota keluarga terdekat, ditemui ada dampak-dampak negatif yang dirasakan oleh mantan pecandu meskipun tidak berupa perilaku-perilaku negatif atau perilaku menyimpang seperti waktu masih menjadi pecandu (Contohnya: berkelahi, tidak menafkahi keluarga, dan lain-lain seperti data ditema sebelumnya). Namun hal itu merupakan dampak negatif yang mengganggu aktivitas keempat subjek setiap harinya. Diakui oleh keempat subjek bahwa dampak yang dirasakan lebih kepada kondisi fisik (tubuh) mereka seperti menderita penyakit lambung, sering mengalami sakit kepala, sakit pada bagian dada, dan juga kulit mereka lebih sensitif. Akibatnya, hal ini mengganggu aktivitas mereka yang terkadang harus ditunda karena kondisi tubuh yang sedang melemah dan sakit.

Subjek 1 dan 4 merasakan nyeri pada bagian perut jika terlambat makan apalagi jika mereka mengonsumsi makanan yang pedas terasa bagian perut mudah menunjukan reaksi kurang nyaman. Reaksi pada perut ini pernah diperiksa oleh dokter hingga dirawat inap dengan alasan karena subjek mengalami maag yang akut. Selain itu, mereka terkadang mengalami nyeri pada bagian dada yang membuat mereka kesulitan untuk tidur. Sedangkan subjek 2 dan 3 mengeluhkan hal yang berbeda yaitu sakit pada kepala dan kondisi kulit yang sensitif. Terkadang pada bagian tangan atau kaki atau seluruh badan kulit mudah berwarna kemerahan, bersisik, dan kering.

\section{Faktor-Faktor yang Mendukung Kondisi Flourishing Pada Subjek Penelitian}

Ada beragam kejadian yang memicu setiap subjek hingga keputusan untuk berhenti menjadi pecandu muncul dari dalam pribadi setiap masing-masing subjek. Pada subjek 1, kejadian yang menjadi pemicu yaitu sakit hingga dibawa ke rumah sakit tapi subjek masih melawan untuk tetap meminum setelah sembuh. Maka ia mengalami sakit lagi yang lebih parah hingga mendapatkan perawatan intensif dari dokter. Adapun diagnosa dokter yaitu subjek mengalami luka pada lambungnya. Kejadian yang memicu subjek 4 yaitu ketika ia dilaporkan oleh istri atas tindakan KDRT hingga masuk penjara. Kemudian istrinya memaafkan dan memberikan kesempatan untuknya bebas dan berubah. Pada saat itu, subjek merasakan kepedulian dan kasih sayang dari istrinya hingga ia mengambil keputusan berhenti menjadi pecandu. Lalu pada subjek 2 dan subjek 3, mereka sudah sampai pada tahapan jenuh dan lelah untuk hidup berkonflik dengan keluarga sendiri, lingkungan sekitar, dan tidak adanya kasih sayang atau perhatian yang diperoleh.

Yang memperkuat hingga setiap subjek mampu menjadi flourisher dalam jangka waktu yang konsisten lebih dari 2 tahun hingga 9 tahun setelah berhenti dari konsumsi alkohol yaitu adanya komitmen dari dalam diri sendiri (faktor internal) yang kuat dan hal ini muncul terlebih dahulu. Lalu faktor kedua berkaitan dengan lingkungan sekitar yaitu dukungannya orang-orang terdekat. Pada subjek yang belum menikah, sosok ibu berperan penting. Pada subjek yang sudah menikah, sosok istri menjadi kunci perubahan. Selain itu, faktor lingkungan lainnya seperti 
lingkup pergaulan yang positif seperti di gereja dan tetangga juga mendukung.

\section{PEMBAHASAN}

Berdasarkan data hasil penelitian dapat dianalisa profil flourishing dari setiap subjek bahwa keempat subjek memiliki level flourishing yang sama yaitu menjadi seorang flourisher. Walaupun durasi waktu berhentinya berbeda-beda dari 2, 4, 5, dan 9 tahun. Lima aspek flourishing yaitu PERMA terlihat ada pada diri subjek baik emosi yang positif yang bahagia, kelekatan dengan pekerjaan yang mereka tekuni dengan rajin, hubungan yang positif dengan keluarga dan orang sekitar, mampu memaknai hidup mereka dengan ikut serta dalam kegiatan-kegiatan rohani, dan memiliki pencapaian dalam kehidupannya.

Law, Shapka, \& Collie (2020) menggambarkan profil dari seorang flourisher yaitu memiliki kemampuan beradaptasi dan menerima keadaan lingkungan sosial yang tinggi, berada pada tingkat depresi dan kecemasan yang rendah. Lalu profil dari orang dengan kesehatan mental moderat yaitu kemampuan adaptasi yang sedang, tingkat depresi dan kecemasan yang diatas rata-rata. Sebaliknya sisi yang paling rendah yaitu profil dari orang yang mengalami languishing yaitu kemampuan adaptasi yang rendah, depresi dan kecemasan pada tingkat yang tinggi. Dibandingkan dengan data hasil penelitian dan melihat proses setiap masingmasing subjek dari seorang pecandu hingga menjadi mantan pecandu alkohol, maka dapat disimpulkan bahwa ketika masih menjadi pecandu keempat subjek berada pada level languishing. Hal ini terlihat dominan di subjek 2 yang menyimpan dendam lama dengan ayahnya dan subjek 4 yang mengalami mimpi buruk dan insomnia hingga pagi. Subjek 1 dan 3 juga nampak dari perilaku agresifnya yang mengganggu kenyamanan keluarga dan lingkungan sekitar. Ke empat subjek merasa hidup hampa dan tidak bermakna karena setiap hari hanya mabuk saja dan tidak memiliki pekerjaan.

Temuan tersebut selaras dengan penelitian Adewuya et al (2017) yang menemukan bahwa kehilangan minat atau kesenangan sebagai gejala depresi yang paling sering terjadi, lalu diikuti dengan pikiran bunuh diri, suasana hati rendah, masalah tidur dan mudah lelah. Gejala depresi dan kecemasan umum memiliki komorbiditas tinggi dengan gejala somatik dan masalah penggunaan alkohol. Pengangguran atau tidak memiliki pekerjaan tetap merupakan salah satu faktor signifikan yang berasosiasi dengan gejala depresi atau kecemasan umum. Dengan memahami betapa sulitnya kondisi subjek yang berada pada level languishing, maka menjadi menarik untuk menganalisa alasan setiap subjek ketika memilih untuk berhenti dari konsumsi alkohol. Karena keputusan tersebut mampu membalikan keadaan mereka dari level languishing ke flourishing. Setiap subjek sudah sampai pada titik yang mana tidak ada pilihan lain lagi selain berhenti menjadi pecandu agar mereka dapat merasakan kebahagiaan dan kedamaian. Bahkan mereka juga merasa menyesal karena pernah menjadi pecandu. Mereka sadar bahwa dengan kondisi flourishing mengubah banyak hal menjadi positif dan menikmati berbagai keuntungan seperti penghasilan dari pekerjaan, memiliki makna hidup, dan memperoleh pencapaian serta prestasi dalam hidup. Keputusan untuk berhenti dari pecandu dianggap sebagai salah satu pencapaian terbesar dalam hidup sehingga terciptanya perasaan bahagia, damai, bangga, bersyukur, dan puas.

Keyes (2015) meneliti tentang flourishing sebagai lambang dari kesehatan mental yang baik. Ia mengalami masalah dengan trauma, depresi, dan kecanduan alkohol. Flourishing adalah hal yang paling ia inginkan dalam hidup dan menjadi penentu ia berhenti dari kecanduan alkohol. Semakin seseorang mengalami flourishing setelah berhenti dari alkohol, maka semakin memberikan motivasi, harapan positif, identitas positif dan nilai hidup yang lebih berharga. Flourishing yang dialami oleh setiap subjek ini punya kaitan erat dengan istilah Complete Mental Health (CMH: kesehatan mental yang penuh/lengkap). Menurut Keyes (dalam 
Fuller-thomson, Agbeyaka, \& Bern-klug, 2016), CMH terdiri atas tiga elemen utama. Yang pertama yaitu tidak adanya sakit mental dalam satu tahun terakhir seperti depresi, kecemasan, kecanduan alkohol atau obatobatan. Kedua, adanya kebahagiaan dan kepuasan dalam kehidupan secara konsisten dalam beberapa bulan terakhir. Ketiga, kesejahteraan sosial yang positif seperti relasi yang akrab dan mendukung dan atau kesejaheraan psikologis. Tiga elemen ini dibandingkan dengan data dari keempat subjek maka disimpulkan keempat subjek memenuhi tiga elemen tersebut. Pada elemen pertama, karena depresi dan kecemasan umum yang komorbid dengan kecanduan alkohol maka ketika subjek berhenti dari kecanduannya maka depresi, kecemasan dan insomnia berkurang cukup banyak. Elemen kedua, setiap subjek merasa lebih bahagia, damai, bersyukur, puas, dan merasakan hidup yang bermakna ketika berhenti dari kecanduan. Elemen ketiga juga terlihat jelas pada semua subjek yang lebih akrab dan harmonis dengan keluarga. Mereka juga lebih aktif mengikuti kegiatan rohani, kerja bakti, dan berkumpul bersama tetangga yang mendukung dan memperkuat perubahan positif subjek.

Elemen ketiga ini juga selaras dengan penelitian dari Schotanus-dijkstra \& Pieterse (2016) yang menyatakan bahwa dukungan sosial dan peristiwa kehidupan yang positif berkontribusi secara signifikan terhadap intensitas flourishing, dengan tetap memperhatikan sosio-demografi dan sifat-sifat kepribadian subjek. Penelitian telah menunjukkan pengaruh besar dari dukungan sosial hingga subjek mengalami kesejahteraan dan flourishing. Jika dibandingkan dengan keadaan setiap subjek yang mampu lepas dari kecanduan alkohol walaupun tidak mendapatkan penanganan atau intervensi psikologis secara khusus, tapi dengan adanya dukungan sosial dan peristiwa kehidupan sebagai pemicu yang membuat subjek mampu mengambil keputusan untuk berhenti dari pecandu. Sebagai tambahan Fuller-thomson, Agbeyaka, \& Bern-klug (2016) menyatakan temuan yang menjanjikan bahwa durasi panjang atau lamanya masa depresi tidak berasosiasi dengan tercapainya CMH. Penelitian menunjukan bahwa subjek dengan dua tahun atau lebih mengalami depresi setara dalam mencapai $\mathrm{CMH}$ dibanding dengan subjek yang baru satu bulan saja. Ke-empat subjek dalam penelitian ini juga mengalami durasi waktu menjadi mantan pecandu yang berbeda-beda yaitu 2, 4, 5, dan 9 tahun namun tetap mampu menjadi seorang flourisher.

Faktor lainnya yang juga berkontribusi dalam flourishing setiap subjek ketika menjadi mantan pecandu yaitu naiknya tingkat spiritualitas dan keterlibatan dalam kegiatan keagamaan di gereja. Vanderweele (2017) menyebutkan bahwa kehadiran dalam kegiatan keagamaan memiliki kaitan dengan meningkatnya perilaku kesehatan termasuk berkurangnya perilaku merokok, berkurangnya penyalahgunaan alkohol dan penggunaan narkoba. Kehadiran dalam kegiatan keagamaan secara longitudinal terkait dengan kondisi kesehatan mental yang lebih baik, termasuk menurunnya intensitas depresi sebanyak 20\% - 30\%. Ada juga bukti bahwa kehadiran dalam ibadah dikaitkan dengan hubungan sosial yang lebih baik.

Selain itu, terdapat pula dampak negatif dari menjadi seorang pecandu alkohol pada masa lalu dan dampak tersebut masih menyisakan efek yang kurang nyaman pada kondisi fisik setiap subjek seperti sakit maag, sering sakit kepala, sakit/nyeri pada bagian dada, dan juga kulit lebih sensitif. Dibandingkan dengan beberapa penelitian didapati bahwa dengan memperhatikan faktor lamanya menjadi pecandu, banyaknya kadar minuman alkohol per hari, faktor genetik, gender, usia, nutrisi, dan aktivitas tubuh sehari-hari maka efek negatif pada kondisi fisik yang dapat dialami oleh pecandu yaitu hipertensi, penyakit kardiovascular (salah satunya gelajanya sakit pada bagian dada), tulang yang lemah, patah tulang pinggul, gastro-oesophageal reflux disease (asam lambung), dan upper digestive diseases (sakit pada pencernaan bagian atas) (Armstrong-Moore, Haighton, Davinson, \& Ling, 2018; Chuang et al., 2017; 
Fisher, Orav, \& Chang, 2018; Ness-Jensen \& Lagergren, 2017; Rehm \& Roerecke, 2017).

Dengan memahami kondisi subjek dan keluarga yang sudah menyatu dengan flourishing secara natural ini, maka solusi yang diberikan untuk keempat subjek yaitu tetap pertahankan pencapaian menjadi flourisher ini dengan cara mengontrol diri dengan baik. Menurut Sarafino (dalam Komasari \& Helmi, 2000) kontrol diri merupakan kemampuan untuk membimbing tingkah laku sendiri. Kontrol diri diperlukan untuk mengatur perilaku yang diinginkan dalam menghadapi apapun sehingga menghasilkan harapan yang diinginkan dan menghindari yang tidak diinginkan. Penguatan penerapan flourishing dapat berdasarkan PERMA oleh Zyl \& Stander (2019) yang menyatakan saran seperti tetap meningkatkan emosi positif, mengembangkan kelekatan, menumbuhkan hubungan positif, menciptakan kebermaknaan dalam hidup, dan mencapai prestasi dalam hidup.

Selain itu, dengan memperhatikan temuan dampak negatif pada kesehatan fisik subjek, maka flourishing juga bisa dilihat dari berbagai sudut pandang penelitian lainnya yang mengkombinasikan dengan variabel kesehatan fisik (biologis), pola hidup sehat, karakter, perspektif teologi, dan emosi negatif (Faul et al., 2019; Langer, Hall, \& McMartin, 2010; Mesurado, Crespo, Rodríguez, Debeljuh, \& Carlier, 2018; Sr, Zyl, \& Rautenbach, 2019). Aspek dan variabel lain yang juga punya kaitan erat dengan flourishing tersebut (khususnya dampak negatif) kurang banyak digali dan dianalisa mendalam pada setiap subjek sehingga menjadi salah satu kelemahan dalam penelitian ini yang perlu diperhatikan oleh peneliti selanjutnya.

\section{KESIMPULAN}

Berdasarkan hasil analisa dan pembahasan maka penulis dapat menyimpulkan bahwa ke-empat subjek dengan durasi waktu berhenti mengonsumsi alkohol yang berbeda-beda telah mengalami flourishing dalam hidup. Hal ini dapat dilihat dari kehidupan keempat subjek yang mengalami perubahan positif seperti mampu menunjukkan emosi yang positif walaupun dalam situasi tertentu yang mengharuskan mereka untuk marah, adanya kelekatan pada setiap pekerjaan, mampu membangun hubungan yang positif dengan orang sekitar, mampu memaknai kehidupan dengan cara lebih dekat dengan Tuhan, dan memiliki berbagai pencapaian positif dalam kehidupan berkeluarga dan bermasyarakat.

Dalam proses untuk berhenti, keempat subjek mengatakan bahwa untuk berhenti mengonsumsi alkohol dibutuhkan niat dan komitmen yang kuat seseorang karena hal ini tidak mudah. Ada beberapa faktor pendukung yang menguatkan setiap subjek yaitu memiliki kemauan dalam diri, relasi dengan keluarga dan lingkungan terdekat, dan alasan kesehatan fisik. Dampak positif yang setiap subjek dapatkan yaitu lebih fokus pada halhal positif misalnya bekerja untuk memenuhi kebutuhan sehari-hari keluarga, memiliki rasa bermakna dalam hidup, memiliki pencapaian sebagai seorang ayah dan anak, ikut serta dalam kegiatan sosial seperti kerja bakti di dalam lingkungan dan kegiatan rohani. Sebaliknya, disisi lain adapun dampak negatif sebagai sisa efek dari kecanduan alkohol sebelumnya seperti kondisi fisik (tubuh) yang mudah lemah dan sakit karena faktor menderita penyakit lambung, sakit kepala, sakit pada bagian dada, dan kulit lebih sensitif.

Dengan memperhatikan dampak positif, dampak negatif, dan kelemahan penelitian maka rekomendasi dari penelitian ini adalah aspek-aspek flourishing dari berbagai sudut pandang teori perlu digunakan dan diterapkan untuk menciptakan intervensi pada kasus kecanduan alkohol, dan gangguan psikologis lain yang saling komorbid seperti depresi, kecemasan, dan insomnia. Rekomendasi untuk penelitian selanjutnya yaitu bisa menggunakan metode kuantitatif dengan skala subjek yang lebih besar untuk melihat dampak negatif (residu) dari pecandu, pengaruh flourishing yang lebih luas pada berbagai kasus kesehatan mental lainnya dengan menggunakan metode eksperimen untuk menguji intervensi flourishing.

\section{DAFTAR RUJUKAN}


Adewuya, A. O., Atilola, O., Ola, B. A., Coker, O. A., Zachariah, M. P., \& Olugbile, O. (2017). Current Prevalence, Comorbidity and associated factors for symptoms of Depression and Generalised Anxiety in the Lagos State Mental Health Survey (LSMHS), Nigeria. https://

doi.org/10.1016/ j.comppsych.2017.11.010

Alsa, A. (2014). Pendekatan Kuantitatif \& Kualitatif serta Kombinasinya dalam Penelitian. Yogyakarta: Pustaka Belajar.

Armstrong-Moore, R., Haighton, C., Davinson, N., \& Ling, J. (2018). Interventions to reduce the negative effects of alcohol consumption in older adults: A systematic review. $B M C$ Public Health, 18(1), 1-13. https:// doi.org/10.1186/s12889-018-5199-x

Aulia, F. (2015). Aplikasi Psikologi Positif dalam Konteks Sekolah. Proceeding Seminar Psikologi Dan Kemanusiaan, 978-979.

Chuang, Y. S., Wu, M. C., Yu, F. J., Wang, Y. K., Lu, C. Y., Wu, D. C., ... Wu, I. C. (2017). Effects of alcohol consumption, cigarette smoking, and betel quid chewing on upper digestive diseases: A large cross-sectional study and meta-analysis. Oncotarget, 8(44), 78011-78022. https://doi.org/10.18632/ oncotarget.20831

Effendy, N. (2016). Konsep flourishing dalam psikologi positif: Subjective well -being atau berbeda. Seminar A sean 2nd Psychology \& Humanity, Universitas Muhammadiyah Malang, Indonesia. Malang: Universitas Muhammadiyah Malang.

Effendy, N., \& Subandriyo, H. (2017).

Tingkat flourishing individu dalam organisasi PT X dan PT Y. EXPERIENTIA: Jurnal Psikologi Indonesia, 5(1), 1-17.

Faul, A. C., D’Ambrosio, J. G., Yankeelov, P. A., Cotton, S. G., Furman, C. D., Hall-Faul, M., ... Pruchno, R. (2019).
Human Flourishing and Integrated Care Models: The Development of the Flourish Index. Gerontologist, 59(6), E653-E663. https://doi.org/10.1093/ geront/gny114

Fisher, N. D. L., Orav, E. J., \& Chang, G. (2018). Effects of alcohol consumption on blood pressure in hypertensive women. American Journal of Drug and Alcohol Abuse, 44(2), 200-205. https:// doi.org/10.1080/00952990.2017.13559 21

Fuller-thomson, E., Agbeyaka, S., \& Bernklug, M. (2016). Author's Accepted Manuscript with a history of depression. Psychiatry Research. https://doi.org/10.1016/ j.psychres.2016.04.041

Keyes, C. L. M. (2015). Flourishing after addiction: An invited commentary on the McGaffin et al . Flourishing after addiction: An invited commentary on the McGaffin et al . ( 2015 ) study. Addiction Research \& Theory, 00(00), 1-3. https:// doi.org/10.3109/16066359.2015.10482 36

Komasari, D., \& Helmi, A. F. (2000). Faktorfaktor penyebab perilaku merokok pada remaja. Jurnal Psikologi, 27(1), 37-47.

Langer, R., Hall, M. E. L., \& McMartin, J. (2010). Human flourishing: The context for character development in Christian higher education. Christian Higher Education, 9(4), 336-360. https:// doi.org/10.1080/15363759.2010.49273 8

Law, D. M., Shapka, J. D., \& Collie, R. J. (2020). Who might flourish and who might languish? Adolescent social and mental health profiles and their online experiences and behaviors. Human Behavior \& Emerg Tech, 2(July 2019), 82-92. https://doi.org/10.1002/ hbe2.172

Lette, A. R., Ratnawati, A. T., \& Swasti, I. K. (2016). Perilaku minum sopi pada remaja di Kecamatan Sopi drinking behavior among adolescents in Kupang. 
BKM Journal of Community Medicine and Public Health, 32(7), 237-244.

Maula, L. K., \& Yuniastuti, A. (2017). Analisis faktor yang mempengaruhi penyalahgunaan dan adiksi alkohol pada remaja di Kabupaten Pati. Public Health Perspective Journal, 2(2).

Mesurado, B., Crespo, R. F., Rodríguez, O., Debeljuh, P., \& Carlier, S. I. (2018). The development and initial validation of a multidimensional flourishing scale. Current Psychology, 8(1), 1-10. https:// doi.org/10.1007/s12144-018-9957-9

Ness-Jensen, E., \& Lagergren, J. (2017). Tobacco smoking, alcohol consumption and gastro-oesophageal reflux disease. Best Practice and Research: Clinical Gastroenterology, 31(5), 501-508. https://doi.org/10.1016/ j.bpg.2017.09.004

Nurulina, N. (2013). Kontrol Diri Pada Pecandu Alkohol. Universitas Muhammadiyah Surakarta.

Parker, P., Banbury, S., \& Chandler, C. (2018). The Utility of Measuring Flourishing in Substance and Alcohol Use Disorders Research ; a Systematic Review. (December 2017).

Prabowo, A. G., \& Pratisti, W. D. (2017). Studi fenomenologis: perilaku agresif pada pecandu alkohol. Prosiding Temu Ilmiah Nasional X Ikatan Psikologi Perkembangan Indonesia, 1. Retrieved from http://jurnal.unissula.ac.id/ index.php/ippi/article/view/2197/1659

Rehm, J., \& Roerecke, M. (2017). Cardiovascular effects of alcohol consumption. Trends in Cardiovascular Medicine, 27(8), 534-538. https:// doi.org/10.1016/j.tcm.2017.06.002

Satori, D., \& Komariah, A. (2011). Metodologi penelitian Kualitatif. cet. III; Bandung: CV. Bandung: Alfabeta.

Schotanus-dijkstra, M., \& Pieterse, M. E. (2016). What Factors are Associated with Flourishing ? Results from a Large Representative National Sample. Journal of Happiness Studies, 17(4), 1351-1370. https://doi.org/10.1007/ s10902-015-9647-3

Sr, S. R., Zyl, L. E. Van, \& Rautenbach, C. (2019). Positive Psychological Intervention Design and Protocols for Multi-Cultural Contexts. In Positive Psychological Intervention Design and Protocols for Multi-Cultural Contexts. https://doi.org/10.1007/978-3-03020020-6

Sugiono, P. D. (2015). Memahami Penelitian Kualitatif. In Bandung: Alfabeta. Bandung: Alfabeta.

Vanderweele, T. J. (2017). Religious Communities and Human Flourishing. Current Directions in Psychological Science, 26(874), 1-6. https:// doi.org/10.1177/0963721417721526

Yuspendi, Y., Handojo, V., \& Handayani, V. (2017). Peran voluntary activities dan coping terhadap perkembangan flourishing. Prosiding Temu Ilmiah Nasional $X$ Ikatan Psikologi Perkembangan Indonesia, 1. Semarang: HIMPSI Indonesia.

Zyl, L. E. Van, \& Stander, M. W. (2019). Flourishing Interventions 2 . 0:A Practical Guide to Student Development (Positive P; R. S. S. Van Zyl L., Ed.). https:// doi.org/10.1007/978-3-030-20020-6 